\title{
The Income ANd Price Elasticity of Demand For HOUSING IN GHANA: EMPIRICAL EVIDENCE FROM HOUSEHOLD LEVEl DATA
}

\author{
Francis Tandoh \\ Department of Economics, University of Zululand \\ Devi Datt Tewari \\ Faculty of Commerce, Administration and Law, University of Zululand \\ Accepted: January 2016
}

\begin{abstract}
Housing is a challenging issue in Ghana, due to the rising demand and sluggish supply which has led to a deficit of more than two million housing units. This study aimed to estimate and analyse the determinants of the demand for housing in Ghana. The estimated elasticities show that owner and rental demand for housing is price and income inelastic. Permanent income elasticities were greater in each case than current income elasticity. The quantile regression showed that permanent income, current income and price were significant for all quantiles of housing units consumed. It is recommended that all these factors be taken into account when addressing the housing supply challenges facing Ghana to help clear the existing deficit and to provide for the anticipated increase in demand due to increasing income, since demand for housing in the country is income inelastic.
\end{abstract}

Key words: demand, elasticity, Ghana, hedonic, permanent income, quantile

JEL: D11, R21

\section{$1 \quad$ Introduction}

Demand for housing $^{1}$ in Ghana is increasing progressively as a result of demographic, economic and social factors. The increasing population is one of the factors which accounts for rising demand in the country. Ghana's population grew from a little more than 2.3 million in 1921 to 26.3 million in 2014. Population estimates for 2014 show that close to 56 per cent of the population is between the ages of 15 and 60 years old (Ghana Statistical Services [GSS], 2014). Smith and Searle (2010) argue that youthful populations increase demand for housing. Figures from GSS (2012), show that the growing population, coupled with a reduction in household size, has resulted in an increase in the number of households. The number of households nearly doubled within 14 years, from 3.7 million in 2000 to 6.6 million in 2014.

Increasing income per capita and improved access to education, particularly tertiary education, also account for the rising demand for housing in Ghana. Gross Domestic Product (GDP) per capita increased from US\$218 in 1970 to $\$ 1841$ in 2013 (GSS, 2013). As income rises, demand for housing also increases for two main reasons: the investment motive and the increase in the demand for housing services.

Finally, changing cultural norms and the fairly stable political and economic environment in Ghana also contribute to the increasing demand for housing. High inflation rates coupled with the continued depreciation of the currency motivate Ghanaians to invest in real estate as a hedge against rising inflation, thus increasing the investment demand for housing (Bank of Ghana [BoG], 2007). For instance, the national currency of Ghana, the Ghana Cedi, depreciated by 31 per cent against the US dollar in the year 2014. Inflation in the same period was 17 per cent and house prices increased by 35.2 per cent in the same period. Investing in property is used as a hedge against the high inflation rate, so Ghanaians would demand a lot of housing units, not only for consumption but for investment purposes as well. 
Despite the growing demand for housing, supply is not able to respond appropriately. For instance, in the year 2000 the demand for housing outstripped supply by about 1.5 million housing units. $^{2}$ This increased to over two million in a period of 14 years in 2014 as shown in Table 1-1. This is due partly to the fact that most housing is supplied by individual households who take between five and 15 years to build a single unit (BoG, 2007). ${ }^{3}$ It is estimated that 4.9 million Ghanaians live in slums scattered around the major cities and towns and that such settlements are growing at a rate of 1.83 per cent per annum (Government of Ghana [GoG], 2005).

Table 1

Demand and supply of housing in Ghana

\begin{tabular}{|l|c|c|c|}
\hline \multicolumn{1}{|c|}{ Year } & Housing demand & Housing supply & Housing deficit \\
\hline 1970 & $1,678,296$ & 941,639 & 736,657 \\
\hline 1984 & $2,410,096$ & $1,226,360$ & $1,184,636$ \\
\hline 2000 & $3,708,250$ & $2,181,975$ & $1,526,275$ \\
\hline 2010 & $5,467,136$ & $3,392,745$ & $2,074,391$ \\
\hline 2014 & $6,601,500$ & $4,207,003^{*}$ & $2,394,497$ \\
\hline
\end{tabular}

In spite of the extensive literature on the demand for housing in developed countries and some developing countries, there is a paucity of empirical studies on Ghana. Malpezzi and Mayo (1987) and Asiedu and Kagaya (1991) conducted empirical studies on demand for housing in Ghana, but each focused on a single city, so their findings cannot be generalised to the whole country. Besides, these studies are too old to represent current realities. Although much has been written on the housing market in Ghana (Obeng-Odoom, 2011, 2010, 2009; Karley, 2008; Asiedu \& Arku, 2009), none of these studies attempted to empirically estimate the elasticity (the degree of responsiveness of dependent variable subject to a unit change in the independent variable) of the various determinants of the demand for housing. This study therefore fills this gap in the literature.

Second, the design and implementation of appropriate urban planning policy depend heavily on price and income elasticity for estimating future increases in the demand for housing. Malpezzi and Mayo (1987) argue that variations in the assumptions of income and price elasticity increase housing subsidy costs by 73 per cent and lead to a 'deadweight' loss to society of 400 per cent. Therefore demand elasticities are a vital input in efficient and appropriate housing policy outcomes. This study aims to provide these elasticities for Ghana.

Third, almost all demand estimations in literature utilise the OLS or other mean-based regression methods that may clad the effects of the various quantiles of housing demand, thereby either underestimating or overestimating the income and price elasticities of the various consumer units; thus wrong estimates can lead to policy failure. This study provides the income and price elasticity of the various quantiles of housing consumption to aid effective housing demand policy and planning in Ghana.

In developed countries, almost every house is tradable but this is not the case in Ghana. Ownership of some houses is not clearly defined: the house belongs to the past, current and future kin of the family. No individual has the power to trade such houses, for any reason. These houses sometimes serve as the family's source of unity. They exist for consumption, social and cultural purposes and not as an investment. The social relations of housing cause some households to remain in the same house, no matter what the sale of that unit would have fetched for the household and how much it would have fetched if redesigned. Although the social relations of housing have dwindled in the bigger cities (UN Habitat, 2011), households in the majority of towns and villages still cling to this belief. This clearly illustrates that in developing and some emerging economies the functioning of the housing market is not the same as in developed countries. Hence the demand conditions are different.

The rest of the paper is organised as follows: Section Two outlines the theoretical and empirical framework; Section Three presents the owner demand estimates; Section Four presents a 
discussion for renter demand estimates; Section Five comprises a comparative analysis of elasticities; while Section Six concludes the study.

\section{Theoretical and empirical framework}

The theoretical framework used housing as a consumer good as elaborated in Zabel (2004). This theory is premised on three fundamental assumptions: that the consumer optimises utility given price and income constraints; the consumer chooses an unobservable homogenous commodity called housing, and that a perfectly competitive housing market exists. The individual household $i$ in market $j$ with the utility function (U) depends on the quantity of housing consumed (q), consumption of other commodities (C) and household demographic characteristics (A), such that the utility for each household is assumed to be constant, although households have different demographic characteristics. The consumption decision of an individual household is therefore characterised by the maximisation of the individual's utility function subject to the budget constraint stated as:

$$
\text { Maximise utility } \underset{q_{i} C_{i j}}{\operatorname{Max}} U\left(q_{i j}, C_{i j}, A_{i j}\right)
$$

Subject to:

$$
\text { Budget constraints } I_{i j}=C_{i j}+p_{j} q_{i}
$$

where $I_{i}$ is the income of the household $i$, the price $C$ (other commodities) is normalised to one and $\mathrm{p}_{\mathrm{j}}$ is the price index of housing which is allowed to differ across markets. Solving the budget constraints in terms of $C_{i j}$ gives

$$
C_{i j}=I_{i j}-p_{j} q_{i j}
$$

substituting equation (3) into the utility function (1) generates

$$
w_{i j}=\operatorname{Max}: U\left(I_{i j}-p_{j} . q_{i j}, q_{i j}, A_{i}\right)
$$

where $w_{i j}$ represents the indirect utility function.

A solution of equation (4) gives the inverse demand function

$$
p=\frac{\partial w_{i}}{\partial q_{i}} / \frac{\partial w_{i}}{\partial I_{i}}
$$

This therefore gives the demand function of housing of the form:

$$
q_{i j}=\left(I_{i}, p_{j}, A_{i}\right)
$$

It is believed that the demand for housing depends on income, price and the demographic characteristics of the household. This has been the fundamental approach in estimating demand (Megbolugbe, Marks \& Schwartz, 1991).

Equation (6) is the demand function to be estimated if all the variables are known. In reality $\mathrm{q}_{\mathrm{i}}$ is unobservable rather than the value of a house $(\mathrm{v})$, which is a function of the characteristics $(\mathrm{z})$ of the housing unit (number of rooms, lot size, etc.) and a parameter which allows for variation in the values across location $(\phi)$. Therefore the values of housing unit $k$ consumed by household i in a market $j$ can be stated as:

$$
v_{k j}^{i}=v\left(z_{k}, \phi_{j}\right)
$$

Equation (7) is the hedonic function expressing the value of a house based on its characteristics. From equation (7), one can obtain the parameter $\phi_{j}$ using hedonic price modelling given the observed value of $v_{k j}^{i}$, and $z_{k}$. Additionally if $z_{k}^{*}$ is defined as a standard unit, then the price 
index can be constructed as:

$$
p_{j}=100 \times \frac{v\left(z_{j}^{*} ; \phi_{j}\right)}{v\left(z_{j}^{*} ; \phi_{1}\right)}
$$

The price index is constructed based on the predicted value of the hedonic estimations for the location or market, where the price index for a market where $j=1$ is taken as the base. This therefore means that the value of a housing unit $\left(v_{k}\right)$ in a housing market $(j)$ for an individual $(i)$ can be expressed as:

$$
v_{k j}^{i}=q_{i j} \cdot p_{j}
$$

Equation (9) postulates that the value of a housing unit in a given market is the product of the price and the quantity of housing units consumed. Therefore the quantity of housing units consumed is shown as:

$$
q_{i j}=\cdot \frac{v_{k j}^{i}}{p_{j}}
$$

Now that $\mathrm{q}_{\mathrm{ij}}, \mathrm{P}_{\mathrm{j}}$ are known and the individual characteristics are observable, it is expected that equation (6) can confidently be estimated. Previous studies (Zabel, 2004) advocate using permanent rather than current income.

There is a rich literature on the demand for housing as a consumer good. This literature focuses on different thematic areas: demand for housing services; demand for housing characteristics; the simultaneous demand for housing quantity and tenure; and demand for housing space and dwelling type.

The demand for housing services is modelled as the services per unit of housing produced by a housing unit as homogenous goods, called housing services (Rouwendal, 1998). Studies in this category include Polinky and Ellwood (1979) who reconciled the differences between micro and aggregate data in explaining the demand for housing services, while Zabel (2004) argued that estimated price and income elasticities of demand for housing were ambiguous because there was no clear definition of housing services. To resolve this ambiguity and to demonstrate that a coherent measure of housing services requires a constant price in all markets whether or not neighbourhood characteristics are included, an empirical study that classified housing demand determinants into neighbourhood characteristics and structural characteristics was conducted.

This approach, based on demand for housing characteristics, examines the specific attributes and neighbourhood characteristics of housing besides income and price as determinants of housing. Ioannides (2002) argued that a neighbourhood has a substantial effect on the demand for housing and that the social interaction effect is much stronger than a household's previous consumption. Ioannides and Zabel (2008) jointly modelled the demand for housing and neighbourhood choice. This enriched Ioannides and Zabel's (2003) study that modelled the demand for housing on the assumption that neighbourhood choice was exogenously determined (neighbourhood choice was determined outside the housing demand framework). They argued that joint modelling of housing demand and neighbourhood choice leads to a consistent estimate despite its complexities, and concluded that ignoring the simultaneous nature of neighbourhood effects and demand for housing biased the estimates.

The third category of housing demand is the simultaneous demand for quantity of housing and tenure choice. Rapaport (1997) stated that a household's housing demand decision was a simultaneous choice between price and quantity given the community of choice, and that the community factor was usually omitted from housing demand models. Therefore the demand for housing was modelled as a 14, dependent on the community and/or tenure status decision and that the price of housing was community- and tenure-specific. House price reflected the available supply of housing given the community and the tax rate, while the price of housing was endogenously determined. Ras, Gameren and Eggink (2005) used a three-step procedure to 
analyse the demand for housing in the Netherlands. The quantity of housing services demand was simultaneously modelled for owner occupiers and renters. Garcia and Hernandez (2008) jointly modelled housing tenure and housing type using micro data from Spain.

Demand for housing space and dwelling type assumes that the consumer measure the attributes of each of the available alternatives. Bajari and Kahn (2005) estimated households' willingness to pay for housing attributes and tenure as well as the dwelling type.

This study adopts the first category and borrows from Zabel (2004) and Fontenla and Gonzalez (2009) in the empirical model to be estimated. This is due to the fact that this model is the most appropriate in the light of the available data. Furthermore, the empirical estimates for the second category require extensive data on neighbourhood characteristics. This presents many complexities in the estimation procedure (Ioannides \& Zabel, 2003). The third category requires the simultaneous estimation of the housing demand and community choice, but due to the extensive nature of the data required to do so, it is practically impossible to adopt this methodology. The final category requires using panel data, so that the choice of households can be observed over time. This requirement makes it impossible for this study to adopt this category. Recent studies indicate that the determinants of housing demand in some developing countries were arrived at utilising the first category. Therefore, this category was adopted for this study due to its flexibility with cross sectional data (Tiwari \& Parikh, 1999; Fontenla \& Gonzalez, 2009).

The empirical estimation of the demand for housing follows three steps: permanent income is estimated in line with the literature (available upon request); the hedonic price model for housing is estimated to help construct a general price index of housing in Ghana (also available upon request); and finally, the demand for housing model is estimated given the quantity, price and other variables.

The quantity of housing consumed $\left(q_{i j}\right)$ from equation (6) is stated as a function of permanent income $\left(I_{p i}\right)$, transitory income $\left(I_{t i}\right)$, and housing-price $\left(P_{j}\right)$, and other variables are specified in logarithmic terms. That is, the estimated demand equation is of the form:

$$
\begin{aligned}
& \operatorname{In}\left(H_{Q T Y}\right)_{i j}=\beta_{0}+\beta_{1} \ln \left(I_{P}\right)_{i}+\beta_{2}\left(I_{T}\right)_{i}+\beta_{3}\left(H_{\text {index }}\right)_{i}+\beta_{4}\left(H H_{\text {age }}\right)_{i}+\beta_{5}\left(H H_{W E D}\right)_{i}+\beta_{6}\left(H_{S I Z E}\right)_{i}+ \\
& \beta_{7}\left(H_{S E X}\right)_{i}+\beta_{8}\left(H H_{E L E}\right)_{i}+\beta_{9}\left(H_{G R A}\right)_{i}+\beta_{10}\left(H H_{U N I}\right)_{i}+\beta_{11}\left(H_{S E C}\right)_{i}+\beta_{12}\left(L_{U R B}\right)_{i}+\varepsilon_{i}
\end{aligned}
$$

Heteroskedasticity-consistent standard error estimators for OLS regression (hc3) were employed (Hayes \& Cai, 2007; Long \& Ervin, 2000). Table 2 provides a description of the variables. The subscript $i$ represents the $i$ 'th household. The variables prefixed with 'HH' denote variables that describe the head of the household. The variables prefixed with ' $H$ ' denote those that describe the housing unit and those prefixed with ' $\mathrm{L}$ ' describe locational variables.

Table 2

\begin{tabular}{|c|c|}
\hline Variable & Description \\
\hline $\mathrm{H}_{\mathrm{QTY}}$ & Quantity of housing units consumed by a household \\
\hline $\mathrm{I}_{\mathrm{C}}$ & Current income of the household \\
\hline$I_{P}$ & Permanent income of the household \\
\hline $\mathrm{I}_{\mathrm{T}}$ & Transitory income of the household \\
\hline $\mathrm{H}_{\text {INDEX }}$ & Estimated price index of housing \\
\hline $\mathrm{HH}_{\text {WED }}$ & A dummy 1 if the household head is married and 0 otherwise \\
\hline $\mathrm{HH}_{\text {SIZE }}$ & The total number of people in the household \\
\hline $\mathrm{HH}_{\mathrm{SEX}}$ & A dummy 1 if the gender of the household head is male and 0 otherwise \\
\hline $\mathrm{HH}_{\mathrm{ELE}}$ & A dummy 1 if the highest education of the household head is elementary school and 0 otherwise \\
\hline $\mathrm{HH}_{\mathrm{GRA}}$ & $\begin{array}{l}\text { A dummy } 1 \text { if the highest education of the household head is a post graduate (master's and doctorate) and } \\
0 \text { otherwise }\end{array}$ \\
\hline $\mathrm{HH}_{\mathrm{SEC}}$ & A dummy 1 if the highest education of the household head is a secondary education and 0 otherwise \\
\hline $\mathrm{HH}_{\text {UNI }}$ & A dummy 1 if the highest education of the household head is university degree and zero otherwise (Honours) \\
\hline LuR & Household stays in the urban localities \\
\hline
\end{tabular}

Description of housing demand variables 


\section{Permanent income equation estimation}

Various authors have used permanent income as the ideal income for housing demand estimation with its justification long established (see Ioannides \& Zabel (2003); Fontenla \& Gonzalez (2009)). Current income $I_{i}$ is made up of transitory $\left(I_{i T}\right)$ and permanent $\left(I_{i P}\right)$ income:

$$
I_{i}=I_{i P}+I_{i T}
$$

Therefore, to obtain permanent income, current income of the household is regressed on the household demographic characteristics. The functional equation is therefore stated as:

$$
\ln I_{i}=a_{i}+X_{i}^{\prime} \beta_{i}+D \gamma_{i}+\varepsilon_{i}
$$

Where $\mathrm{I}_{\mathrm{t}}$ is the observed income of the household, $x_{p}^{\prime}$ is the personal characteristics that determine permanent income, and $D$ is a vector of regional dummies. The predicted values become the permanent income while the residuals become the transitory income.

\section{Owner-occupier households}

\subsection{Descriptive statistics}

The descriptive statistics show that, on average, Ghanaians consume 3,434 units of housing per year with a standard deviation of 2965. The skewness value shows that a smaller number of households consume more housing units than the average unit. This means that the quantity of housing consumed is not evenly distributed.

The kurtosis value confirms the non-normality of the quantity of housing units demanded. The average household size of five shows that owner-occupiers have bigger households compared with other tenure status considered in this study, since the overall average household size in Ghana is four. The statistics for graduate education are highly skewed, showing only a few graduate household heads. The coefficient of skewness shows that the income of most of these households falls below the mean income. Owner occupation was higher in the rural areas (58 per cent) than the urban areas (42 per cent). Finally, Table 3 shows that 67 per cent of owner-occupier household heads are married. The mean price index for owner-occupied households was 176.8 and the average housing units consumed by a household was 7.5. Owner-occupier households have an average current monthly? annual? income of about GhC600edis (equivalent of US\$600) with a standard deviation of 2.6 and a permanent average income of GhC650 with a standard deviation of 1.5. This shows that there is more inequality in current income than there is in permanent income.

Table 3

A description of owner occupier in Ghana

\begin{tabular}{|l|c|r|r|r|r|r|r|}
\hline Variable & Observation & \multicolumn{1}{|c|}{ Mean } & $\begin{array}{l}\text { Standard } \\
\text { deviation }\end{array}$ & Minimum & Maximum & Skewness & Kurtosis \\
\hline $\mathrm{I}_{\mathrm{C}}$ & 4016 & 15.59179 & 1.291181 & 9.601383 & 20.08293 & -0.316 & 3.45 \\
\hline $\mathrm{I}_{\mathrm{P}}$ & 2285 & 15.66157 & .3344995 & 14.56954 & 16.94431 & -0.11 & 3.22 \\
\hline $\mathrm{L}_{\mathrm{URB}}$ & 4135 & .2309553 & .4214948 & 0 & 1 & 1.29 & 2.6 \\
\hline $\mathrm{H}_{\text {INDEX }}$ & 4135 & 100.8845 & 3.661875 & 98.48336 & 112.0798 & 13.41 & 6.83 \\
\hline $\mathrm{H}_{\text {SIZE }}$ & 4135 & 5.046191 & 3.104306 & 1 & 29 & 1.3 & 6.97 \\
\hline $\mathrm{H}_{\text {QTY }}$ & 4135 & 3434.217 & 2965.993 & 548.8026 & 23326.53 & 3.33 & 15.17 \\
\hline $\mathrm{HH}_{\text {AGE }}$ & 4135 & 50.32938 & 15.79087 & 17 & 99 & 0.39 & 2.57 \\
\hline $\mathrm{HH}_{\text {GRA }}$ & 2285 & .0083151 & .0908271 & .49 & 1 & 10.8 & 118 \\
\hline $\mathrm{HH}_{\text {ELE }}$ & 2285 & .4297593 & .49515 & 0 & 1 & 0.284 & 1.08 \\
\hline $\mathrm{HH}_{\text {SEX }}$ & 4135 & .7639661 & .4246946 & 0 & 1 & -1.24 & 2.54 \\
\hline $\mathrm{HH}_{\text {WED }}$ & 4135 & 0.673518 & 0.468911 & 0 & -0.74 & 1.55 \\
\hline
\end{tabular}

Source: Estimation 


\subsection{Owner occupier elasticities}

The estimated elasticities for owner-occupier households show that six variables are significant determinants of demand for owner-occupier housing demand. Except for price, all the significant variables were positive, as shown in Table 4 . The estimated permanent income elasticity shows that demand for housing in Ghana is income inelastic (housing demand is less responsive to changes in permanent income). This could be due to three possible reasons. The property market in Ghana is currently in its infancy. There is also no social housing, since the houses that did exist were divested or reserved for public sector workers. The only alternative to owning a home is private rental housing. This alternative presents many problems, including substandard housing, high rent advances and significant shortages in some areas, leading to higher rents. This suggests that the best option for a household is to move to owner-occupancy which they can do if their income increases. The next possible explanation for the lack of income elasticity is borrowed from Brounen et al. (2012), who argued that homeowners benefit from high inflation since house prices rise in an inflationary period and the value of owner-occupiers' property also increases. Since Ghana is a highly inflationary country, households demand owner- occupation as a hedge against inflation as well as for the capital gains associated with it.

The final reason is the need to hedge against the risk of rent increases. Sinai and Souleles (2003) argued that the hedge against future high rent payment forces households to move to owner-occupation. The acute shortage of housing units in Ghana - especially standard, quality housing - means that households who rent, pay high rents. In order to hedge against higher rents in the future, households would move to owner-occupancy with an increase in income. This finding corresponds with the findings of other studies. For example, Malpezzi and Mayo (1987) found owner income-elasticity for Egypt to be 0.17, while Mehta and Mehta (1989) estimated owner-income elasticity for India to be 0.2 . The quantile estimation shows that the income elasticity of the demand for the various quantiles of housing units is less than the OLS (mean) estimates. The income elasticity of the lowest 25 per cent of quantiles is greater than the income elasticity for the top 25 per cent of housing consumers, although the elasticity for both is less than the median elasticity (0.5Q) shown in Table 4 . The quantile elasticities show the need to account for the different units in the elasticity estimation so that reliable policy inferences can be drawn from it with little variation.

The price elasticity of demand for owner-occupation shows that the price of housing does not necessarily affect the demand for owner-occupier housing in Ghana significantly. This could be ascribed to the mode of housing finance systems in Ghana. Most households finance their houses with savings or use the incremental housing method ${ }^{4}$ therefore an increase in the price of housing does not affect the consumption of housing since the interest rate effect does not come into play. Increases in house prices in Ghana are the result of increases in the value of land and the cost of building materials (Bank of Ghana, 2007). As such, an increase in house prices leads to increases in the cost of alternatives or substitutes for owning, that is, in private rental prices which are already very high in Ghana due to the acute shortage of housing and the hefty requirement of twoto five-year advance payments. An increase in the price of housing leads to a slowdown in the rate at which households add to their building, thus restricting the quantity of housing units owneroccupiers can consume, although this will be very marginal. The dynamics of the housing market do not make the usual shift from owner-occupation to rental housing easy: the costs involved also deter most owner-occupiers in Ghana from maintaining their status despite house price increases. Therefore the elasticity truly reflects the fundamental characteristics of the housing market in Ghana.

The estimated price elasticity is less than the literature for developing countries proposes. Mayo (1981) proposed 0.38 to 0.37 and the recent findings of studies by Fontenla and Gonzalez (2009) confirmed this. Follain, Lim and Renaud (1980) achieved a near zero price elasticity of owneroccupation in South Korea, while Malpezzi and Mayo's (1987) estimate for owner- occupied elasticity in Cairo and Manila was close to 1 or unity in absolute terms. The price elasticity 
estimates were also in line with current estimates for Spainwhich range from -0.002 to -0.04 (Garcia \& Hernandez, 2008) and the USA where Zabel (2004) found elasticity of -0.001 using 1993 data and -0.011 for 2001 data. The variation in the estimates of the price elasticity is due to variations in the definitions of the price and the models used in the estimation, as well as the procedure and data used in obtaining the price index (Zabel, 2004).

Mayo (1981) argued that the different demographic characteristics across countries make it difficult to make comparisons, therefore it is preferable to restrict discussion to the country under study. The OLS estimates show that the gender of the household head, household size and the age and marital status of the head of the household were not significant determinants of the demand for housing in Ghana. However, the quantile estimates show that the gender of the household head was insignificant only in the lowest 25 per cent of housing consumers. The size of the household was significant in all the quantiles despite not being significant in the OLS estimation. The elasticity from the level of education shows that elementary education was an insignificant determinant of the demand for housing in the top 25 per cent of consumption units but university education was significant at all levels of consumption.

Table 4

Owner occupier demand elasticity (OLS and quantile)

\begin{tabular}{|c|c|c|c|c|}
\hline Variable & OLS & $0.25 Q$ & $0.5 Q$ & $0.75 Q$ \\
\hline $\mathrm{HH}_{\mathrm{SEX}}$ & .0017 & -.0023 & .0032 & .0039 \\
\hline $\mathrm{HH}_{\mathrm{SIZE}}$ & .0041 & $.0097^{\star \star *}$ & $.0076^{\star \star *}$ & $.0058^{*}$ \\
\hline $\mathrm{HH}_{\mathrm{AGE}}$ & .0064 & $.0152^{\star \star \star}$ & .0063 & .0083 \\
\hline $\mathrm{HH}_{\text {URB }}$ & $.0439^{\star \star \star}$ & $.0306^{\star \star \star}$ & $.0445^{\star \star \star}$ & $.0576^{\star \star \star}$ \\
\hline $\mathrm{HH}_{\text {GRA }}$ & $.0003^{*}$ & $.0004^{\star * *}$ & $.0005^{\star \star *}$ & $.0002^{* *}$ \\
\hline $\mathrm{HH}_{\mathrm{ELE}}$ & $.0027^{\star *}$ & $.0022^{*}$ & $.0026^{\star *}$ & .0021 \\
\hline $\mathrm{H}_{\text {INDEX }}$ & $-.0983^{\star * *}$ & $-.1079^{\star \star \star}$ & $-.1002^{\star \star \star}$ & $-.0934^{\star \star \star}$ \\
\hline${ }^{\# I_{P}}$ & $.1719^{\star \star \star}$ & $.1548^{\star * \star}$ & $.1620^{\star * \star}$ & $.1329^{\star *}$ \\
\hline${ }^{\#} I_{C}$ & $.1682^{* * *}$ & $.1113^{\star * *}$ & $.1431^{* * *}$ & $.1311^{* * *}$ \\
\hline \multirow[t]{2}{*}{$\mathrm{HH}_{\text {WED }}$} & .0020 & $.0059^{* *}$ & .0011 & .0008 \\
\hline & $R^{2}=0.6834$ & $R^{2}=30$ & $R^{2}=20$ & $R^{2}=22$ \\
\hline \multicolumn{3}{|c|}{ Ramsey RESET } & \multicolumn{2}{|c|}{$F(3,5436)=1.28 . \quad$ Prob $>F=0.278$} \\
\hline
\end{tabular}

\#Permanent income $\left(I_{p}\right)$ and current income $\left(I_{C}\right)$ were estimated in the model separately

Source: Estimation

\subsection{Rural and urban owner demand elasticities}

A breakdown of the demand estimates (both OLS and quantile) for the rural and urban locations in Ghana shows that permanent income was the major determinant of the demand for housing in urban localities, while current income was the major determinant of demand for housing in rural ones. This finding is consistent with the conditions prevailing in these two localities. Most of Ghana's rural dwellers are subsistence farmers. This means that they have no permanent and consistent source of income or expectation of one; they therefore consume housing based on their current income (usually related to harvests from their farming activities).

In contrast, most urban dwellers work in the formal sector and earn a regular income so they have expectations of a permanent income for consumption purposes. Therefore the permanent income elasticity for the urban areas was greater than the current income. The permanent income elasticity for the median urban housing unit consumer was within the range advocated by Malpezzi (1999). The wide difference in permanent income elasticity between urban and rural localities might account for the smaller lower level of the overall elasticity reported above.

The elasticity of the educational variables shows that elementary education was only significant in the urban areas and not the rural ones. Even in the urban areas the quantile estimates show that it determined consumption only in the lowest 25 per cent of units. While permanent income and level of education were the major determinants of the demand for housing in urban localities, 
current income, age of the household head, gender of the household head and size of the household were the major determinants of the demand for housing in the rural localities in Ghana (Table 5).

Table 5

OLS and quantile elasticities for owner demand (urban and rural locations)

\begin{tabular}{|c|c|c|c|c|c|c|c|c|}
\hline \multicolumn{5}{|c|}{ Urban Ghana } & \multicolumn{4}{|c|}{ Rural Ghana } \\
\hline Variable & OLS & $0.25 Q$ & $0.5 Q$ & $0.75 Q$ & OLS & $0.25 Q$ & $0.5 Q$ & $0.75 Q$ \\
\hline $\mathrm{HH}_{\text {SEX }}$ & -.0080 & -.0015 & .0071 & .0006 & $.0112^{* * *}$ & -.0004 & .0033 & .0059 \\
\hline $\mathrm{HH}_{\text {SIZE }}$ & -.0004 & -.0056 & $-.0198^{*}$ & -.0043 & .0030 & $.0129^{\star \star \star}$ & $.0119^{\star \star \star}$ & $.0090^{\star *}$ \\
\hline $\mathrm{HH}_{\mathrm{AGE}}$ & -.0010 & .0083 & -.0213 & -.0066 & $.0114^{\star *}$ & $.0153^{\star * *}$ & $.0104^{\star \star *}$ & $.0157^{\star *}$ \\
\hline $\mathrm{HH}_{\text {GRA }}$ & .0006 & $.0018^{\star \star *}$ & .0010 & .0002 & .0008 & .0008 & -.0002 & .0003 \\
\hline $\mathrm{HH}_{\mathrm{ELE}}$ & $.0063^{* *}$ & $.0082^{* *}$ & .0051 & .0034 & .0004 & .0008 & .0012 & .0010 \\
\hline $\mathrm{HH}_{\text {INDEX }}$ & $-.087^{\star * \star}$ & $-.079^{\star \star \star}$ & $-.075^{\star \star \star}$ & $-.086^{\star \star *}$ & $-.104^{\star \star *}$ & $-.118^{\star * *}$ & $-.107^{\star \star \star}$ & $-.095^{\star \star \star}$ \\
\hline${ }^{\prime} I_{p}$ & $.3335^{\star *}$ & .1077 & $.6146^{\star *}$ & $.5986^{\star \star *}$ & .0400 & .0544 & .0545 & .0069 \\
\hline${ }^{*} \mathrm{I}_{\mathrm{C}}$ & $.2749^{* * *}$ & $.2464^{\star \star *}$ & $.2947^{\star \star *}$ & $.2029^{\star \star \star *}$ & $.0952^{* * *}$ & $.0599^{\star * *}$ & $.1107^{\star \star \star}$ & $.1070^{\star \star \star *}$ \\
\hline \multirow[t]{2}{*}{$\mathrm{HH}_{\text {WED }}$} & .0011 & .0015 & -.0071 & .0059 & .0022 & $.0075^{\star \star \star}$ & .0032 & -.0013 \\
\hline & $R^{2}=0.70$ & $R^{2}=0.43$ & $\mathrm{R}^{2}=0.20$ & $R^{2}=0.25$ & $R^{2}=0.56$ & $R^{2}=0.17$ & $R^{2}=0.27$ & $R^{2}=0.45$ \\
\hline
\end{tabular}

\#Permanent income $\left(I_{p}\right)$ and current income $\left(I_{C}\right)$ were estimated in the model separately.

Source: Estimation

\section{$5 \quad$ Rental households}

\subsection{Descriptive statistics}

The descriptive statistics show that rental Ghanaian households on average consumed 5,684 units of housing per year with a standard deviation of 8508 . The value of the skewness is 3.7 which shows that a smaller number of households consumed more units than the average. This means that the quantity of the housing consumed was not evenly distributed.

The kurtosis value confirms the non-normality of the quantity of rental housing demand. There were extremes in the rental housing market. Statistics for household size again show that size was not evenly distributed across households. The average household size of three shows that rental households had fewer members than owner-occupiers. Statistics relating to education show high skewness of graduate education in Ghana and renting. Only a few rental household heads had a graduate qualification. In terms of basic education, the statistics show that it was normally distributed across heads of rental households in which almost half had elementary education. Marital status was normally distributed among households (Table 6).

Table 6

Descriptive statistics of the rental households in Ghana

\begin{tabular}{|l|c|r|r|r|r|r|r|}
\hline \multicolumn{1}{|c|}{ Variable } & Observation & \multicolumn{1}{c|}{ Mean } & $\begin{array}{l}\text { Standard } \\
\text { deviation }\end{array}$ & Minimum & Maximum & Skewness & Kurtosis \\
\hline $\mathrm{H}_{\text {QTY }}$ & 1751 & 5684.319 & 8508.616 & 38.07523 & 108000 & 5.3947 & 47.5561 \\
\hline $\mathrm{HH}_{\mathrm{SIZE}}$ & 1751 & 3.432324 & 2.216011 & 1 & 15 & 0.8701 & 3.7026 \\
\hline $\mathrm{HH}_{\mathrm{SEX}}$ & 1751 & .7230154 & .4476366 & 0 & 1 & -0.9966 & 1.9934 \\
\hline $\mathrm{HH}_{\text {AGE }}$ & 1751 & 39.63564 & 12.21151 & 15 & 99 & .8006 & 3.8388 \\
\hline $\mathrm{HH}_{\text {GRA }}$ & 1434 & .0062762 & .0790007 & 0 & 1 & 12.5035 & 157.339 \\
\hline $\mathrm{HH}_{\text {ELE }}$ & 1434 & .4825662 & .4998703 & 0 & 1 & 0.0697 & 1.004 \\
\hline $\mathrm{L}_{\text {URB }}$ & 1751 & .8023986 & .3983035 & 0 & 1 & -1.5188 & 3.3069 \\
\hline $\mathrm{H}_{\text {INDEX }}$ & 1751 & 73.9825 & 94.63124 & 100 & 423.5961 & 1.6525 & 4.7242 \\
\hline $\mathrm{I}_{\mathrm{P}}$ & 1177 & 15.74017 & .4221134 & 14.25577 & 17.15092 & -.1381 & 2.8320 \\
\hline $\mathrm{I}_{\mathrm{C}}$ & 1751 & 15.8920 & 1.1942 & 10.7289 & 19.2981 & -.7490 & 4.2819 \\
\hline $\mathrm{HH}_{\text {WED }}$ & 1751 & .508281 & .5000742 & 0 & 1 & 1.001 & -.0331 \\
\hline
\end{tabular}

Source: Estimation 


\subsection{Rental elasticities}

The rental income elasticity shown in Table 7 indicates that renting is income inelastic in Ghana. Permanent income elasticity is greater than current income elasticity and both are statistically significant. The rental income elasticity reveals three important aspects of the Ghanaian housing market in general and the rental market in particular. The high positive income elasticity shows the rental arrangement which prevails in the country. To rent in Ghana, one needs to make a payment at least two years in advance. This amount often exceeds current income so people have to borrow money in order to afford the consumption of the housing units they desire. Most Ghanaians use their permanent income to rent, therefore when it increases, they increase their level of consumption, since they can now pay higher instalments on the loans they took out to rent the unit they occupy. This elasticity is similar to the findings of Malpezzi and Mayo (1987) for Kumasi, the second largest city in Ghana. It also compares favourably with the findings of Garcia and Hernandez (2008). The quantile breakdown shows that income elasticity for the median housing consumer is less than the average elasticity (OLS) estimate (Table 7). This means that the income elasticity provided by the OLS model overestimates the elasticity for the majority of the population. Therefore, any policy based on the OLS estimation would marginalise the majority of the population of housing consumers in the country. The lower 25 per cent of consumers rent out of current rather than permanent income, as their permanent income is not statistically significant.

Rental price elasticitiy estimates show that renters respond massively to changes in price. Rental elasticity is clearly greater than the price elasticity estimate for owner occupiers. This confirms Goodman and Kawai's (1984) assertion that the high transaction cost of switching tenure from ownership to renting makes the price elasticity of renting greater than that of owning. The estimated renter price elasticity for this study corresponds with the findings of Zabel (2004).

Table 7

Demand elasticity estimates for renters

\begin{tabular}{|c|c|c|c|c|}
\hline Variable & OLS & $0.25 Q$ & $0.5 Q$ & $0.75 Q$ \\
\hline $\mathrm{HH}_{\mathrm{SEX}}$ & .0052527 & .0059035 & $.010274^{\star *}$ & .0075398 \\
\hline $\mathrm{HH}_{\text {SIZE }}$ & $.0117822^{*}$ & .0142176 & $.0144635^{\star \star *}$ & $.0211013^{*}$ \\
\hline $\mathrm{HH}_{\mathrm{AGE}}$ & -.0047853 & -.0046689 & .0028192 & -.0218723 \\
\hline $\mathrm{HH}_{\text {URB }}$ & $.095078^{* * *}$ & $.0839834^{\star * *}$ & $.0929751^{* * *}$ & $.1056695^{\star * *}$ \\
\hline $\mathrm{HH}_{\mathrm{GRA}}$ & $.0009607^{* * *}$ & $.0011127^{* * *}$ & $.0009005^{\star \star *}$ & $.0008451^{* \star *}$ \\
\hline $\mathrm{HH}_{\mathrm{ELE}}$ & .0006612 & $.0085033^{*}$ & -.0025104 & .0002458 \\
\hline $\mathrm{H}_{\text {INDEX }}$ & $-.6991811^{\star * *}$ & $-.6970408^{* * *}$ & $-.6462982^{\star \star \star}$ & $-.688394^{\star \star \star}$ \\
\hline$I_{P}$ & $.3015381^{* *}$ & .1263437 & $.284841^{* \star *}$ & $.3363613^{*}$ \\
\hline $\mathrm{I}_{\mathrm{C}}$ & $.274615^{* * *}$ & $.2848616^{* * *}$ & $.211408^{* * *}$ & $.2609944^{* * *}$ \\
\hline \multirow[t]{2}{*}{$\mathrm{HH}_{\text {WED }}$} & -.0006464 & -.0017595 & $-.0065741^{\star \star}$ & -.0002878 \\
\hline & $\mathrm{R}^{2}=0.8234$ & $\mathrm{R}^{2}=0.34$ & $\mathrm{R}^{2}=0.44$ & $R^{2}=0.36$ \\
\hline \multicolumn{5}{|c|}{ Ramsey RESET: $F(3,5436)=1.28$. Prob $>F=0.278$} \\
\hline
\end{tabular}

Source: Estimation

Age was expected to have a negative effect on renting since younger households save to buy a home or to make the payment needed by the mortgage market (Cho, 2010), but it was found not to be statistically significant. The explanation may be that the effect of age on renting is not important in the rental market in Ghana. Inheritance and the long period of transition from renting to ownership (if indeed it eventually occurs) might be the reason. The age elasticity contradicts the findings of Asiedu and Kagaya (1991), who undertook a similar study in Kumasi. While the current study found age to be statistically insignificant but negative, their study found it positive which contradicts the literature - but significant. The reason for this might be the more limited scope of Asiedu and Kagaya's (1991) study area compared with the scope of the current study which considers the rental sector in the country as a whole. The estimated results show that education correlates positively with rental housing demand. This can be explained by the fact that most highly educated people work outside their places of origin. They mainly work in cities and 
towns where it is expensive to own a home, which explains why university graduates have the highest positive relationship with renting. Marital status shows an inverse relationship with renting, but it was statistically insignificant except at the median consumption level.

\subsection{Rural and urban rental demand elasticities}

The breakdown of rural and urban statistics confirms the popularity of renting in urban localities relative to rural localities. Permanent income elasticity shows that urban households' rental decisions were influenced by permanent and current income, except at the lowest 25 per cent of housing consumers. These households based their rental decision only on current income. In the rural localities, however, rental decisions were based on current income, except the median consumer units (Table 8).

The price elasticities show that both urban and rural rental decisions were mainly influenced by the price of renting. This is the only variable that showed significance in both localities and at all quantiles of housing consumption. The highest price elasticity was recorded at the top 25 per cent of housing consumers. The estimated elasticities show that urban consumers were more sensitive to price changes than those in the rural localities. The quantile estimates for the two localities show that while the top 25 per cent had the highest elasticity value for price in the rural localities, in the urban localities, the lowest 25 per cent displays the highest elasticity. In the rural areas the elasticity was reduced with increasing quantile, while in the urban areas it decreased from the lowest quantile, increased from the median quantile, and peaked at the highest quantile.

The results show that university education, current income and price were the main determinants of renting in urban localities. These were significant in all quantile and OLS estimates for the urban localities. In the rural localities, however, price was the main determinant and, to some extent, current income as well. Age was consistently shown to be insignificant in both rural and urban localities and at all quantiles. The size of the household was only significant at the median and top 25 percentile of consumers in rural localities. The gender of the household head showed positive and significant effects in all quantiles in the urban areas, although it was insignificant in the OLS estimates. In the rural localities however, only the OLS and the median estimates for household size were significant. The household size showed a positive effect in the instances where it was significant, which means that male-headed households were more likely to rent than female-headed households. Rental by graduates was not applicable in the rural localities and was thus omitted in the estimations. Elementary education, however, was only significant at the lowest 25 percentile of urban consumers. Marital status was consistently shown to be an insignificant factor in rental housing demand in both rural and urban localities and at all quantiles, except the median consumer in the rural localities.

Table 8

Rental demand elasticity estimates for rural and urban localities

\begin{tabular}{|c|c|c|c|c|c|c|c|c|}
\hline \multirow[b]{2}{*}{ Variable } & \multicolumn{4}{|c|}{ Urban localities } & \multicolumn{4}{|c|}{ Rural localities } \\
\hline & OLS & $0.25 Q$ & $0.5 Q$ & $0.75 Q$ & OLS & $0.25 Q$ & $0.5 Q$ & $0.75 Q$ \\
\hline $\mathrm{HH}_{\text {SIZE }}$ & .0105 & .0033 & .0088 & .0037 & .02078 & .0333 & $.0333^{* * *}$ & $.0282^{*}$ \\
\hline $\mathrm{HH}_{\text {SEX }}$ & -.0040 & $.01918^{*}$ & $.01418^{\star \star}$ & $.0203^{\star *}$ & $.0247^{*}$ & .0356 & $.0213^{\star * *}$ & .0004 \\
\hline $\mathrm{HH}_{\mathrm{AGE}}$ & .0014 & -.0036 & .0040 & -.0193 & -.0095 & -.0531 & -.0091 & .0060 \\
\hline $\mathrm{HH}_{\text {GRA }}$ & $.0011^{* \star *}$ & $.0014^{* * *}$ & $.0010^{* * *}$ & $.0010^{* * *}$ & (omitted) & omitted & omitted & omitted \\
\hline $\mathrm{HH}_{\mathrm{ELE}}$ & .0021 & $.0126^{\star \star}$ & -.0027 & .0030 & -.0037 & -.0063 & -.0032 & -.0003 \\
\hline $\mathrm{HH}_{\text {INDEX }}$ & $-.707^{\star \star *}$ & $-.698^{\star * *}$ & $-.652^{* * *}$ & $-.717^{\star * *}$ & $-.633^{\star * \star}$ & $-.662^{* * *}$ & $-.603^{* * *}$ & $-.54^{* * *}$ \\
\hline$I_{P}$ & $.3591^{* *}$ & .1355 & $.3085^{* *}$ & $.3874^{* *}$ & -.0828 & .0307 & $.4433^{* *}$ & -.0633 \\
\hline $\mathrm{I}_{\mathrm{C}}$ & $.2601^{* * *}$ & $.2149^{\star \star *}$ & $.2270^{\star \star *}$ & $.2500^{\star * *}$ & $.3378^{* * *}$ & .2575 & $.3516^{\star * *}$ & $.2520^{\star *}$ \\
\hline \multirow[t]{2}{*}{$\mathrm{HH}_{\text {WED }}$} & .0020 & .0005 & -.0053 & .0042 & -.0158 & -.0144 & $-.024^{* \star *}$ & -.0085 \\
\hline & $\mathrm{R}^{2}=0.92$ & $\mathrm{R}^{2}=0.53$ & $\mathrm{R}^{2}=0.50$ & $\mathrm{R}^{2}=0.50$ & $\mathrm{R}^{2}=0.40$ & $\mathrm{R}^{2}=0.26$ & $\mathrm{R}^{2}=0.20$ & $\mathrm{R}^{2}=0.15$ \\
\hline
\end{tabular}

Source: Estimation 


\section{A comparison of elasticities}

\subsection{Owner demand elasticities}

The Chow test (a test of whether the coefficients estimated over one group of data was equal to coefficients estimated over another) for the owner-occupier households shows that there were significant differences between the income elasticities for the overall estimates for the country and the various localities. This is evident in Tables 3 and 5. For instance, there is a significant variation between the permanent income estimates for the overall country and the various localities. The estimated coefficient for the urban localities is greater than the overall estimates $(0.33$ for urban and 0.17 for urban). The estimated coefficient for the rural localities is not significant. This and others might have contributed to the significant differences obtained from the Chow test. Generally, the differences are due to the rural/urban setting in the Ghanaian economy. Thereare vast differences between rural and urban housing units and housing conditions. This means that a policy or an inference based on the estimates for the whole population will not achieve the desired results. Hence there is the need to separate the estimates for the demand for owner-occupied housing elasticities from rental demand elasticities. Other variables that showed significant differences included the size of the household and the level of education (Table 9). However, the price elasticities are the same whether one considers the whole country or a particular locality. This means that the effect of a price change on owner demand is similar nationwide. Age, marital status and the gender of the household head also have similar elasticities, irrespective of the locality or the segment of the population considered.

Table 9

Comparative analysis of owner demand elasticities

\begin{tabular}{|l|l|l|}
\hline \multicolumn{1}{|c|}{ Variable } & \multicolumn{1}{c|}{$\mathrm{x}^{\mathbf{2}}$ Test } & \multicolumn{1}{c|}{ Decision } \\
\hline $\mathrm{I}_{\mathrm{C}}$ & $46.2(0.0000)$ & Significant difference \\
\hline $\mathrm{I}_{\mathrm{P}}$ & $5.67(0.0588)$ & Significant difference \\
\hline $\mathrm{HH}_{\text {SIZE }}$ & $17.3(0.0002)$ & Significant difference \\
\hline $\mathrm{HH}_{\mathrm{SEX}}$ & $1.45(0.4841)$ & No significant difference \\
\hline $\mathrm{HH}_{\text {AGE }}$ & $0.51(0.7737)$ & No significant difference \\
\hline $\mathrm{HH}_{\text {GRA }}$ & $6.78(0.0336)$ & Significant difference \\
\hline $\mathrm{HH}_{\text {ELE }}$ & $5.77(0.0558)$ & Significant difference \\
\hline $\mathrm{HH}_{\text {WED }}$ & $0.15(0.9289)$ & No significant difference \\
\hline $\mathrm{H}_{\text {INDEX }}$ & $0.18(0.9134)$ & No significant difference \\
\hline
\end{tabular}

Source: Estimation

Table 10

Comparison of rental demand elasticities

\begin{tabular}{|l|c|l|}
\hline \multicolumn{1}{|c|}{ Variable } & \multicolumn{1}{c|}{$\mathrm{x}^{2}$ Test } & \multicolumn{1}{c|}{ Decision } \\
\hline $\mathrm{I}_{\mathrm{C}}$ & $0.18(0.9118)$ & No significant difference \\
\hline $\mathrm{I}_{\mathrm{P}}$ & $2.02(0.3642)$ & No significant difference \\
\hline $\mathrm{HH}_{\mathrm{SIZE}}$ & $0.23(0.8909)$ & No significant difference \\
\hline $\mathrm{HH}_{\mathrm{SEX}}$ & $2.40(0.3016)$ & No significant difference \\
\hline $\mathrm{HH}_{\mathrm{AGE}}$ & $0.03(0.9871)$ & No significant difference \\
\hline $\mathrm{HH}_{\text {GRA }}$ & $41.6(0.0000)$ & Significant difference \\
\hline $\mathrm{HH}_{\text {ELE }}$ & $0.48(0.7883)$ & No significant difference \\
\hline $\mathrm{HH}_{\text {WED }}$ & $2.88(0.2366)$ & No significant difference \\
\hline $\mathrm{H}_{\text {INDEX }}$ & $2.84(0.2422)$ & No significant difference \\
\hline SOuUCe: Estimation & & \\
\hline
\end{tabular}




\subsection{Rental demand elasticities}

The test for similarity among the elasticity for the various rental demands for housing shows that with the exception of graduate education, all other variables had the same effect whether or not the whole population or specific localities are taken into account. This means that a change in income had the same effect on rental housing in the country, whether one considers a rural or an urban locality. The same applies to the price and other elasticities (Table 10). The similarities can be explained by the fact that the whole rental market has a similar pattern in terms of providers and the type of housing, as well as housing conditions.

\section{Conclusion}

This study aimed at filling a gap in the literature in relation to the housing situation in Ghana, providing both the mean and quantile housing demand estimates for the country. It was undertaken because the housing market in Ghana, like most African countries, is practically different from that of the developed and other emerging economies. The study estimated and analysed the demand elasticities for owner-occupier housing units and rental housing units. Estimates for rural and urban locations were conducted employing both the OLS and quantile regression techniques. The estimated elasticities show that owner demand for housing is price- and income-inelastic. Permanent income elasticity was greater than current income elasticity and the price elasticity was close to zero. The quantile breakdowns show the significance of permanent and current income and price. The quantile estimates show that the OLS (mean) sometimes overestimates the income elasticities (See Table 4). The rural and urban breakdown of variables shows that besides price, permanent income is the main determinant of ownership in the urban localities, while current income is the main determinant of ownership in the rural localities. Price effect is greater for rural localities than for urban localities. Permanent and current income, graduate education, urban location, household size and price are the factors that determine the demand for renting. These variables have more of an impact on higher quantiles of housing demand than on lower quantiles. The rural and urban estimates exhibit the same trend as the overall estimates. This means that for policy efficiency the various quantiles of the housing estimates must be used instead of the OLS (mean) estimates. The results based on the quantile estimates show that stakeholders in the housing industry need to take into account not only locality differences but quantile differences as well, if they seriously wish to improve policies governing the housing situation in Ghana for the benefit of her population.

\section{Endnotes}

1 The United Nations (UN) defines a house as "a structurally separate and independent place of abode such that a person or group of persons can isolate themselves from the hazards of climate such as storms and the sun".

2 A housing unit is a separate and independent place of abode intended for habitation by a single household or one not intended for habitation but occupied as living quarters by a household at the time of the census (UN Statistics Division).

3 It must be noted that some houses are completed earlier than the stated period but this is rare.

4 That is, they build as and when money becomes available.

\section{References}

ASIEDU, A.B. \& KAGAYA, S. 1991. A cross-section analysis of household rental housing demand Kumasi city, Ghana. Hokkaido University, Japan.

ASIEDU, A.B. \& ARKU, G. 2009. The rise of gated housing estates in Ghana: Empirical insights from three communities in metropolitan Accra. Journal of Housing and the Built environment, 24(3):227-47.

BAJARI, P. \& KAHN, M.E. 2005. Estimating housing demand with an application to explaining racial segregation in cities. Journal of Business and Economic Statistics, (23)1:20-33.

BANK OF GHANA. 2007. The housing market in Ghana. Accra: Ghana.

BROUNEN, D., EICHHOLTZ, P.A.M., STRAETMANS, S. \& THEEBE, M.A.J. 2012. Inflation protection from homeownership: Long-run evidence. SSRN: http://dx.doi.org/10.2139/ssrn.2158633 : 1814-2008. 
FOLLAIN, J.R., LIM G.-C. \& RENAUD, B. 1980. The demand for housing in developing countries: The case of Korea. Journal of Urban Economics, 7.

FONTENLA, M. \& GONZALEZ, F. 2009. Housing demand in Mexico. Journal of Housing Economics, 18:1-12.

GARCIA, J.A.B. \& HERNANDEZ, J.E.R. 2008. Housing demand in Spain according to dwelling type: Micro econometrics evidence. Regional Science and Urban Economics, 38:363-377.

GHANA STATISTICAL SERVICES. 2012. The 2010 population and housing census: Summary of final report. Accra: Ghana.

GHANA STATISTICAL SERVICES. 2013. Ghana living standards survey report of the fifth round (GLSS 6). Accra: Ghana.

GHANA STATISTICAL SERVICES. 2014. Ghana living standards survey report of the fifth round (GLSS 6). Accra: Ghana.

GOODMAN, A.C. \& KAWAI, M. 1984. Functional form and rental housing market analysis. Urban Studies, 21:367-376.

GOVERNMENT OF GHANA. 2005. Growth and poverty reduction strategy: 2006 - 2009. National Development Policy Commission. Accra Ghana.

HAYES, A.F. \& CAI, L. 2007. Using heteroscedasticity-consistent standard error estimators in OLS regression: An introduction and software implementation. Behavior Research Methods, 39:709-722.

IOANNIDES, Y.M. 2002. Residential neighbourhood effects. Regional Science and Urban Economics, 32 : 145-165.

IOANNIDES, Y.M. \& ZABEL, J.E. 2003. Neighbourhood effects and housing demand. Journal of Applied Econometrics, 18:563-584.

IOANNIDES, Y.M. \& ZABEL J.E. 2008. Interactions, neighbourhood selection and housing demand. Journal of Urban Economics, 63:229-252.

KARLEY, N.K. 2008. Ghana residential property delivery constraints and affordability analysis. Housing Finance International, 22 (4):22-29.

LONG, J.S. \& ERVIN, L.H. 2000. Using heteroscedasticity consistent standard errors in the linear regression model. American Statistician, 54:217-224.

MALPEZZI, S. 1999. Economic analysis of housing markets in developing and transition economies. In: Mills, E.S., Cheshire, P. (eds.) Handbook of regional and urban economics. Pp. 1791-1864.

MALPEZZI, S. \& MAYO, S.K. 1987. The demand for housing in developing countries: Empirical estimates from household data. Economic Development and Cultural Change, 35(4):687-721.

MAYO, S.K. 1981. Theory and estimation in the economics of housing demand. Journal of Urban Economics, 10:95-116.

MEGBOLUGBE, I.F. MARKS, A.P. \& SCHWARTZ, M.S. 1991. The economic theory of housing demand. Journal of Real Estate Research, 6:381-393.

MEHTA, M. \& MEHTA, D. 1989. Metropolitan housing market: A study of Ahmadabad. New Delhi: Sage. OBENG-ODOOM, F. 2009. Real estate agents in Ghana: A suitable case for regulation? Regional Studies: $1-14$.

OBENG-ODOOM, F. 2010. Urban real estate in Ghana: A study of housing-related remittances from Australia. Housing Studies, 25(3):357-373.

OBENG-ODOOM, F. 2010. Private rental housing in Ghana: Reform or renounce? Journal of International Real Estate and Construction Studies, 1(1).

OBENG-ODOOM, F. 2011.Private rental housing in Ghana: Reform or renounce? Journal of International Real Estate and Construction Studies, 1(1):71-90.

POLINKY, A.M. \& ELLWOOD, D.T. 1979. An empirical reconciliation of micro and grouped estimates of the demand for housing. Review of Economics and Statistics, 6:119-205.

RAPAPORT, C. 1997. Housing demand and community choice: An empirical analysis. Journal of Urban Economics, 42:243-260.

RAS, M., GAMEREN E. V. \& EGGINK, E. 2005. The demand for housing services in the Netherlands. $45^{\text {th }}$ congress of the European Regional Science Association, Amsterdam:1-22. 
ROUWENDAL, J. 1998. On housing services. Journal of Housing Economics, 7:218-242.

SINAI, T. \& SOULELES, N. 2003. Owner-occupied housing as a hedge against rent risk. Working paper 9462, NBER.

SMITH, S.J. \& SEARLE. B.A. 2010. The blackwell companion to the economics of housing: The housing wealth of nations. United Kingdom: Wiley-Blackwell:42-43.

TIWARI, P. \& PARIKH, J. 1999. Effective housing demand in Mumbai (Bombay) metropolitan region. Urban Studies, 36(10):1783-1809.

UN-HABITAT. 2011. Housing profile in Ghana, United Nations Human Settlements Programme, Nairobi, Kenya.

ZABEL, J.E. 2004. The demand for housing services. Journal of Housing Economics, 13(1):16-35. 